\title{
Worlds of difference, different worlds: geographies of globalization
}

\author{
Norman Backhaus, Christian Berndt, Benedikt Korf, \\ Ulrike Müller-Böker, Zürich
}

\section{Introduction}

What do Ethiopian pastoralists, Kirgiz migrants, peasants in North-West Pakistan or Mexican workers in industrial offshore plants have in common? They are all part of a struggle to make ends meet, and while doing so, they increasingly need to cross borders and move to or interact with different worlds. They are entangled in «geographies of globalization», which generate a process through which a radical renegotiation of the spatialities of social, economic and political relations takes place.

Sharing a commitment to north-south relations and a concern for processes of uneven development and fragmentation, our research focuses on these different worlds: it engages with the lifeworlds of people in various localities around the globe and how these worlds are connected across different places; how objects and subjects move and are moved across space, as reflected in the mobility of people (e.g. commuting, labour migration, flight, tourism), goods (e.g. commodity chains), capital (e.g. global production systems, humanitarian aid) and ideas (such as «development») as well as in the things, structures and dynamics which create friction, such as borders (state or other) or social and cultural boundaries.

The paper first describes the dialectical relation between stasis and motion that runs through three of the research fields we are currently working on at the Department of Geography, University of Zurich: «People: Migration», «State: Frontier» and «Economy: Geographies of marketization». It maps out a conceptual landscape of geographies of globalization as worlds of difference, as the uneven geographies of movement and persistence, of flow and friction, of openness and boundaries, of modernity and its others - and of those that benefit and those that loose. The article then examines in more detail how geographies of globalization come into being in each of these fields: (1) «People: Migration» studies the multi-local connections and social spaces of migrants, (2) «State: Frontier» engages the intricate relationship between state, territory and the question of where «the state ends» and (3) «Economy: Geographies of marketization» is concerned with the emergence of market orders and their uneven spatial and social expansion.

\section{Geographies of globalization}

Through the process of globalization, space has increasingly transformed into a bundle of relations which are constituted in interaction and mediated medially, communicatively, biographically, economically and politically; interactions that remain temporally and spatially undetermined (BERNDT \& BOECKLER 2011: 1062). In this context our focus is on the contradictions and irritations, the paradoxical intertwining between here and there, between presence and absence, between stability and mobility, and between local and global designs of life. We look into how relations of difference and sameness are articulated, and we are sensitive to the power asymmetries underlying the question of whose knowledge, sayings and doings are counting (such as the influence of Eurocentrism on the emergence of western understandings of entities such as economy, society, culture or state as «global facts»).

In order for the emergence of particular ideas about the world as universal global facts to be successful, it is crucial to have a «benchmark», an understanding of the other. In the discourse of globalization this is often connected to the distinction between modern and traditional or developed and underdeveloped, thereby dividing the inside of such a modernizing project from its outside or other. Constituted and performed socially, this boundary is particularly effective when it materializes spatially, and when it assumes linear temporal form. Once people take the existence of such a boundary for granted, it can then be flexibly adjusted to move people and things in and out and to include what belongs to this side of the boundary and exclude what is beyond. This exacerbates global inequalities as exclusion results in lack of capabilities and freedom to develop (SEN 1999).

Together with capitalism, «development» has arguably been the single most important transformative force in the global south (EscoBAR 2008: 9). In current neoliberal times these transformations take on a particular spatial form: we live in a period when more and more people are forced to renegotiate the balance between stability and mobility to an extent probably not experienced before. Many geographers tend to frame these processes as an irreconcilable opposition - stable, place-based, and embedded sociality on the one hand, fluid translocal and disembedded forms of social life on the other. We side with those who are critical of this view. We do not take corresponding dualisms as pre-given, but rather see them as the never completed effects of the struggles over one's own place in the 
world, the continuous making and unmaking of identities and identifications that create and transform global-local worlds. Neither do we regard globalization as an entirely homogenizing process, by which the local is overrun or even obliterated by the global (BACKHAus 2009; Robertson 1995).

From such a perspective, the debate in the discipline about demands for a flat spatial ontology (MARSTON et al. 2005) in order to better understand our contemporary world risks falling again into a dualism of methodological territorialism and a perspective that methodologically represents the world as exclusively mobile, fleeting and borderless. In our view there can only be one viable ontology: modest, anti-foundational, antiessential, that is, in other words, «flat». But this does not imply that we live in a flat world without scales and hierarchies. On the contrary, such a pragmatic approach to the world allows us to pay full justice to the struggles and conflicts and the inequalities they bring about - as being socially constructed, produced and performed, not as natural facts.

We will now look closer at three research fields where we have applied such thinking to empirical questions of the geographies of globalization.

\section{People: Migration}

People connect rural and urban places within and between countries to diversify their sources of income (e.g. Bebbington 1999; Borras 2009; de HaAn \& Rogaly 2002; de HaAn \& Zoomers 2005; SchmidtKALLERT 2009). Located at the intersection of geographical development and migration studies (e.g. GEISER et al. 2011; THIEME 2008), our research is particularly concerned with the phenomenon of migration in South and Central Asia. In both regions, history has shown in different ways that borders are not given but contested and that they are subject to change. Not denying the agency of migrants and the liberating potential of migration, many people experience the global distribution of capabilities as deeply unequal and see themselves at the downside of economic development. In such cases, migration is not so much a matter of choice but a force of mobilisation in view of securing income.

Despite increasing mobility, people generally remain attached to places and seem to hold onto «their roots.» One characteristic of many migrants who work abroad is their strong attachment to their home country. What is changing, though, among the younger generations is that on the one hand, after their return home, more and more establish their future in urban areas rather than in their villages of origin. In such cases, most people sustain a multi-local life with transnational and national, urban and rural linkages (THIEME et al. 2011). On the other hand, attachments to the home as well as chances for upward social mobility are changing. PörTNER et al. (2011) found that a third generation of former Nepali migrants, who had settled down in the lowlands of Nepal, no longer migrated to neighbouring India for work.

While remittances play a significant macroeconomic role (Fig. 1), migration experiences are much more ambiguous (United Nations Development ProGRAMME - UNDP 2009). Under conditions of postmodernity, powers of geographical mobility for capital and labour are not evenly available and therefore shape who migrates and where (HARveY 1990: 234). Migration policies, laws and regulations filter people's mobility. These restrictions have contributed to a growth of activities in the informal and illegal sectors. They restrain contact to the home and disperse responsibilities over various places, thus blocking the social mobility of migrants (BARBORA et al. 2010).

Nevertheless, this marginalization only applies to part of the migrant group. Skilled and educated migrants often receive a different sort of welcome (WESCOT \& BRINKERHOFF 2006). The likelihood is high that these migrants will transfer new knowledge gained between different knowledge communities by building «bridges» (Williams 2007; Zoomers et al.2009). Generally, knowledge is seen as a fundamental source of well-being and progress, thereby representing developmental potential for developing countries (TEJADA GUERRERo \& Bolay 2005: 2; UNESCO 1998). This potential of knowledge has led to a shift in discourse on knowledge migration from one on brain and labour force drain to one exploring notions of globalization, brain circulation and exchange (DE HAAS 2010). This change has led to a greater polarisation between migrants who are skilled and those who appear to lack useful skills (KoFmAN 2007). The ascription of technological and knowledge innovation as the driving force of globalization and of the formation of a post-modern knowledge society has led to greater esteem being given to highly skilled persons. «Lower skilled» and «unskilled» labourers do not fit into the modernizing scheme. Consequently, they are prevented from crossing borders or, if they are allowed to enter a country, they do not enjoy the same rights as those who are considered more useful to the growth of the knowledge economy (Kofman 2007).

This mobility of labour is embedded in international and often globalised structures of demand and recruitment of labour. The Gulf countries, for example, exercise such a labour and development model, where large numbers of lower skilled workers, but increasingly also high skilled workers, are selectively recruited 


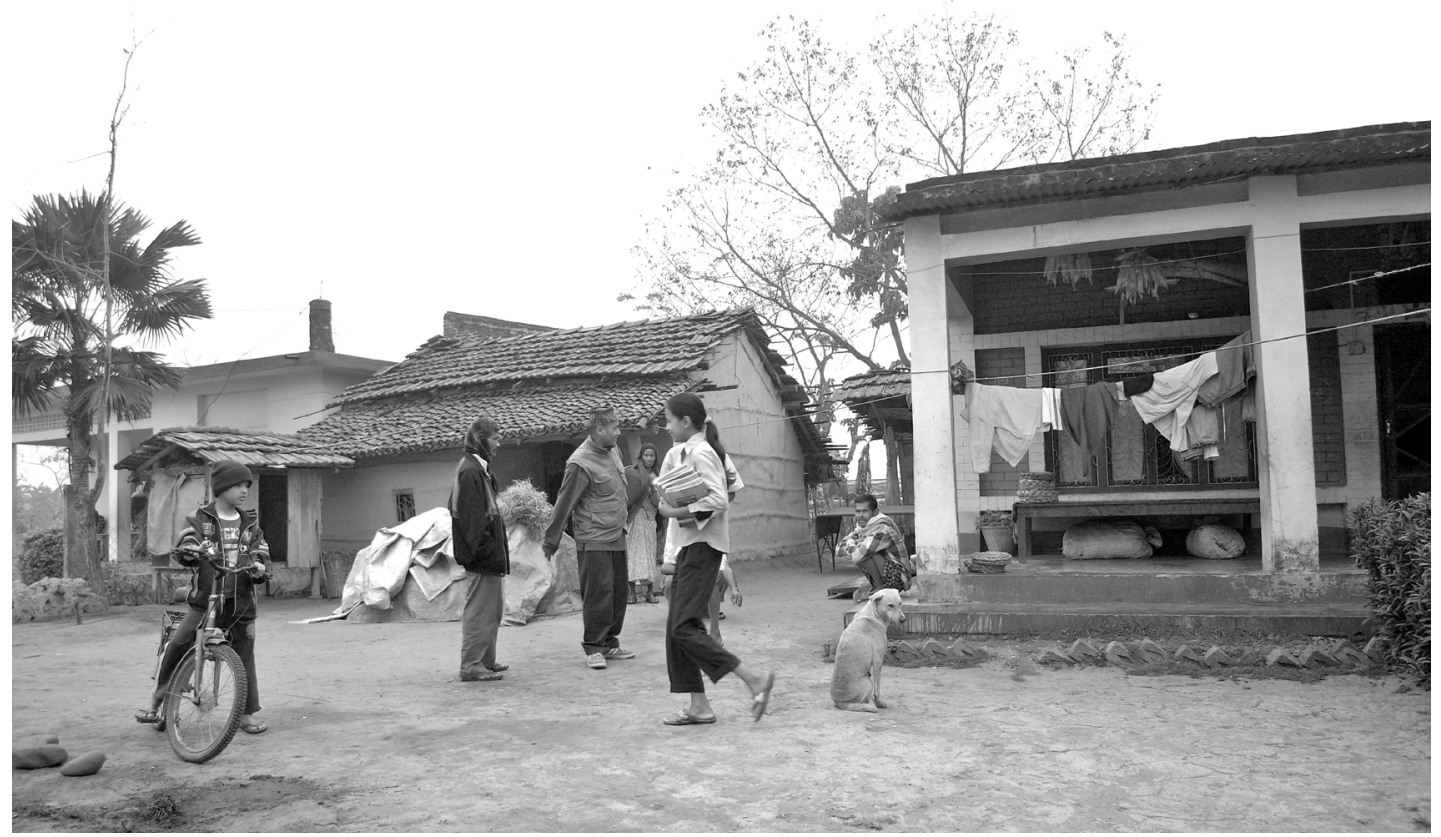

Fig. 1: A major part of the modern houses that are built beside traditional dwellings in the Nepalese Terai are financed by remittances from migrants working in India or the Gulf states.

Ein grosser Teil der im nepalesischen Terai neben traditionellen Häusern errichteten modernen Gebäude wird durch Rimessen von Migranten finanziert, die in Indien oder den Golfstaaten arbeiten.

Au Terai népalais, une grande partie des maisons modernes bâties à côté des bâtiments traditionnels est financée par les fonds des migrants qui travaillent en Inde ou dans les Etats du Golfe Persique.

Photo: N. BACKHAUS

and allowed to immigrate for work. This illustrates how economic relations due to labour mobility go far beyond remittances and need to include the operation of recruiting agencies, communication, travel and logistical technology, as well as money transfer institutions (e.g. GUARNIZO 2003).

\section{State: Frontier}

TALAL AsaD's seemingly innocent question «where does the state end?» (ASAD 2004) brings us to yet another core puzzle within the political geographies of globalization. While scholars on neoliberalism tend to ask when does the state end by identifying a time geography of its demolition versus an ever stronger global financial capitalism, we frame the end of the state spatially: where does the presence of the state diminish, vanish or end? What happens in places where the state has never really established itself? And how are these places connected to the metropolitan cores through often fragmented geographies of sovereignty? We are interested in these questions as some of our research areas, for example, the Pakistani-Afghan, the Ethiopian-Somali or the Congolese-Ugandan borderlands, exhibit characteristics of spaces with limited statehood presence; many of these places have been subjected to the experience of prolonged violent conflict and social and political instability.

The idea of the unambiguous, unitary sovereignty that a state holds over a territory, the

«modern assumption of hard〉 boundaries within which 100 percent sovereignty prevails and beyond which it [disappears] altogether» (Sсотт 2009: 59)

is in this case not appropriate. Global peripheries and their borderlands are characterized rather by a geography of sovereign power which resembles «a diffuse glow» (ibid.) shining from core to periphery. JAMES Scotr reminds us that peripheries are often spaces of 
multiple sovereignty - spaces where different (mostly distant) power holders struggle over control and allegiance of its often scattered populations. This situation has often allowed people inhabiting these peripheries to juggle different loyalties, allegiances and alliances. Our suggestion is that the concept of «frontier» provides a useful framework by which to grasp these fluid and fragile geographies of core-periphery relations.

\section{Donnan (2001: 1290) defines «frontier» as}

«... [a zone] of cultural overlap, characterized by a mixing of cultural styles. They are luminal spaces, simultaneously dangerous and sites of creative cultural production open to cultural play and experimentation as well as domination and control.»

But most often, the frontier is «a fault line and ... a contested zone ... a zone of conflict and competition» (REID 2011: 22). Often, but not always, frontiers emerge along state borders or larger civilization divides, e.g. between sedentary farm lands and pastoralist rangeland livelihoods or between lowland wetland civilizations and upcountry people. The frontier signals the space of encounter and transition between different geographies of settlement patterns, political organization and economic surplus generation from more spatially dense to looser and less intensive modes of livelihoods. From the point of view of the metropolitan core, the former tends to be labelled as «civilization» while the latter is considered a civilizational carte blanche - an empty space or unruly hinterland, where a state of nature prevails pitting Barbarian folks against each other. The teleological rationale of modernity and globalization has it, of course, that the latter spaces are just remnants from a pre-modern past, destined to extinction in the longer run.

The erection of territorial borders has often been a measure by the metropolitan core to map out sovereign power in the frontier. But what kind of order emerges at the border? Is the border the end of one and the beginning of another order (Migdal 2004: 5)? Or does the border as a space develop its own order? At the same time, border could have several meanings, not only territorial state border, but also social boundary, e.g. between different "civilizations» or ethnic groups (BARTH 1969). Boundaries entail a spatial and a relational component; they include symbolic and social dimensions that are marked in maps, but may also signify other dividing lines that cannot be found on maps. Border, then, is not so much a line, as a relation - a relation between core and periphery, which develops its own logic of rule. Frontier is thus not a borderline - a boundary dividing territorial containers of statehood or civilizations from «not yet» civilized empty territory. It is rather a zone of encounter
(GEIGER 2008), of mutual penetration and interference; a territorial space with specific characteristics of violence and order, a specific geography of sovereign power and rule.

While boundaries are mental constructs in a way, they are constantly moulded and transformed in the daily struggle between different governing logics (KoRF et al. 2010). This is especially apparent in contexts of violent political conflict and transition, where one frequently observes a radical pluralisation of such governing norms and regulations. Borders are also fluid. Because governing logics often conflict and overlap, the exercise of boundary drawing by a multiplicity of powerful actors is also frequently contested. And that is where ordinary people (e.g. Sri Lankan paddy farmers, Congolese petty traders, Ethiopian pastoralists, but also clandestine immigrants between Africa and Europe) find a window of opportunity - however small and temporary - to cut through the time-space that is imposed on them by powerful actors and institutions. This space of agency and contestation is the entry-point for our field work in such borderlands, but also in the interstitial and fuzzy frontiers that emerge within the battlefields of violent rebellion and civil war (e.g. Nepal, Sri Lanka).

Three basic propositions can be derived from these studies: First, political borders and social boundaries often do not overlap. The important task of political actors (in order to acquire authority) is not only to make these two match but also to make this overlap appear legitimate and acceptable. Second, bordering processes and political ordering are often part of the same dynamic. To create political order one needs to erect and implement borders (frequently with violent means). Third, borders are fluid. It is important to remember that this b/ordering process is never completed, but continues to involve important «struggles over geography» (WATTS 2000) - a re-writing of space and political legitimacy.

\section{Economy: Geographies of marketization}

Markets are everywhere and nowhere. Given that there is currently hardly a social field and geographical area not exposed to the extension of the principles of market transactions, they are the very stuff our contemporary global age is made of. It is surprising in the light of this omnipresence that the social sciences, until recently, did put greater effort into developing a more sophisticated understanding of markets. Particularly in our contemporary era of neoliberal market orientation, there is a need to view the market as a process in its own right. Markets involve a process of anonymisation, of social ties cutting, of rational, calculative and 
efficient post-social coordination. In line with CALISKAN and CALLON (2010:2), this modality of economization may be referred to as «marketization» (BERNDT \& BOECKLER 2012).

In its broadest understanding, «geographies of marketization» open up new perspectives towards the emergence of market orders and their continuous spatial and social expansion (and their contribution to the construction of societies in general). Markets are conceived of as socio-technical «agencements» (CALLON 2007) - that is, arrangements of people, things and socio-technical devices - that form products, prices, competition, places of exchange and mechanisms of control, whilst taking seriously the constellations of distributed agency that make processes of marketization possible. These arrangements of heterogeneous elements (e.g. conventions, rules, technical devices, infrastructures, logistical procedures, calculating systems, texts, discourses, scientific knowledge, embodied skills, human beings) organize the circulation of goods, together with the property rights attached to them, through the contradictory encounter of quantitative and qualitative valuations. The term «agencement» mobilizes this heuristic setup perfectly. It conveys the idea of a (spatial) assemblage of heterogeneous elements that have been carefully arranged as well as the notion of agency; agencements are thus

«socio-technical assemblages endowed with the capacity to bring about agency, to act and to give meaning to action» (CALLON 2007: 319 ff.).

In addition to previous conceptualizations of markets, two new elements play a crucial role: «things» and «science», or more precisely, «market devices» and «economics» which recursively inform and intervene in processes of marketization. To start with the latter, neoclassically-oriented economists or neoliberal free trade advocates are not simply aiming to understand and explain the world better; rather, with these theories is linked a desire to transform the world. This may happen in multiple ways: the intervention of economics may translate into the intervention of economists themselves, as is the case when academic economists act as consultants to a particular firm, marketplace, government, or regulatory body (MitcheLl 2009). In other instances, economists produce tools and instruments (such as pricing formulas or macroeconomic models) which are then put to practical use by market actors or policy makers - «economists in the wild» in the words of Michel Callon.

However, processes of marketization are not only recursively informed by economic knowledge, they are also socio-technically distributed. A wide spectrum of market devices - from analytical techniques to pric- ing models, from purchase settings to merchandising tools, from trading protocols to aggregate economic indicators, from computer screens to shopping carts intervene in the construction of concrete markets and bring about calculative agency in a distributed manner (see Muniesa et al. 2007). These devices prominently intervene in the framing of concrete markets, in the formatting of exchange mechanisms and evaluation processes. They foster distributed calculative processes and contribute to individualization processes that bring economic and social realities in line with the models of the neoclassical laboratory.

There are various ways to apply this perspective empirically. One example is the concern with markets as discursive borderlands in a north-south context, that is, the «extension of market agencements» on a meso-level and macro-level (and the resistance thereto). The term «borderlands» alludes to the crucial insight that marketization is not simply about colonizing non-market terrain and turning everything, everywhere and everybody into the same. Instead, what appears as a clearly demarcated outside of a bounded entity (the market) is in fact a constituent part of the inside. The non-economic or non-market plays the role of a stranger inside the gate, «the other» that is neither fully inside nor outside. These arrangements literally move people and things in and out, they include and exclude. In so doing, an appearance of a strict separation of entities and realms is produced which in fact are closely connected. Either side emerges as the mirror-image of the other, the modern economy being everything the outside is not.

The stress on the inclusionary-exclusionary nature of marketization is crucial. It allows an understanding of this process as inherently dis/entangled, turning our attention to the everyday practices of value creation, devaluation and exclusion that reproduce the uneven geographies of global capitalism. These processes always involve a paradoxical double movement of entanglement - the conjunctural connections of commodities, people and places - and disentanglement - complex processes of separation and exclusion - that constitute circuits of commodity production. People, things and places are literally moved in and out of such circuits, often creating unstable «borderlands» between non/market relations produced, in part, through struggles over redistribution and control, irreducible to a singular logic of capital.

Geography is an indispensable part of this process for it is the materialization of economic and social differences in the form of the spatial border which completes the translation work. The global movements of capital, goods, people and ideas always involve an ambivalent double play of de-bordering and bordering 
processes. These ambivalent border regimes are a necessary condition for the construction of global markets and production systems. Yet, in order for these to work, the ambivalences have to be hidden and veiled. What is more, the more objects and subjects travel and cross borders, the more borders are themselves moving around, and in particular so in cases when borders display their selective force through their potential to produce a complex amalgam of multiple, often deeply unequal exclusionary differentiations: North/ South, Economic/Non-economic, Modern/Traditional (see Berndt \& Boeckler 2011).

\section{Outlook}

Looking at the world from a perspective that does not regard the dualisms of space and place, local and global, (post-)modern and traditional, or similar, as pre-given entities, calls for research that seeks to reveal how such dualisms are constructed and performed. Assuming a «flat» world when analysing conflicts, mobilities, marketizations or other, geographical research can unveil implicit, tacit, or invisible borders and boundaries that lie behind the explicitly drawn out or established ones. Our research ventures towards disclosing such invisible borders. In addition to the three research fields discussed above, this disclosure is also being studied in relation to practices of appropriation, production and consumption of space and spatialities in different contexts and places (i.e. in public space, in protected areas, through large scale land acquisitions), especially in the use and transformation of «natural» and «cultural» resources (i.e. water, forests, landscapes, knowledge systems, forms of capital). Ethiopian pastoralists, Kirgiz migrants, peasants in North-West Pakistan or Mexican workers may not have much in common, but they share an everyday engagement with the geographies of globalization.

\section{Acknowledgements}

The three research fields sketched in this article are the result of collaborative projects in and beyond Zurich: the discussion on «People: Migration» is the result of collaborations and discussions among Susan Thieme, Ephraim Poertner and Ulrike Müller-Böker; the section on «State: Frontier» draws on collaborations and discussions among Urs Geiser, Tobias Hagmann, Bart Klem, Benedikt Korf and Timothy Raeymaekers; «Geographies of marketization» is a collaborative project between Christian Berndt and Marc Boeckler.

\section{References}

AsAD, T. (2004): Where are the margins of the state. - In: Das, V. \& D. Poole (eds): Anthropology at the margins of the state. - Santa Fe: School of American Research Press: 279-288.

BACKHAUs, N. (2009): Globalisierung. - Braunschweig: Westermann.

Barbora, S., Thieme, S. \& K.A. Siegmann (2010): Patterns and politics of migration in South Asia. - In: Hurni, H. \& U. WiesmanN (eds): Global change and sustainable development: a synthesis of regional experiences from research partnerships. $-=$ Perspectives of the Swiss National Centre of Competence in Research North-South, Vol. 5, Berne: 313-328.

BARTH, F. (ed.) (1969): Ethnic groups and boundaries: the social organization of culture difference. - Bergen, Oslo: Universitetsforlaget, London: George Allen \& Unwin.

Bebbington, A. (1999): Capitals and capabilities: a framework for analysing peasant viability, rural livelihoods and poverty. - In: World Development 27, 12: 2021-2044.

Berndt, C. \& M. Boeckler (2012): Geographies of marketization. - In: Barnes, T., Peck, J. \& E. ShepPard (eds): The Wiley-Blackwell companion to economic geography. - Chichester: Wiley: 199-212.

Berndt, C. \& M. Boeckler (2011): Performative regional (dis-)integration: transnational markets, mobile commodities and bordered North-South differences. - In: Environment and Planning A 43, 5: 1057-1078.

Borras, S.M. Jr. (2009): Agrarian change and peasant studies: changes, continuities and challenges - an introduction. - In: The Journal of Peasant Studies 36, 1:5-31.

Caliskan, K. \& M. Callon (2010): Economization, part 2: a research programme for the study of markets. - In: Economy and Society 39, 1: 1-32.

Callon, M. (2007): What does it mean to say that economics is performative? - In: MacKenzIE, D., Muniesa, F. \& L. Siu (eds): Do economists make markets? On the performativity of economics. - Princeton, N.J.: Princeton University Press: 311-357.

De HaAn, A. \& B. Rogaly (eds) (2002): Special issue on: labour mobility and rural society. - In: The Journal of Development Studies 38, 5.

De Haan, L. \& A. Zoomers (2005): Exploring the frontier of livelihoods research. - In: Development and Change 36, 1:27-47.

De HaAs, H. (2010): Migration and development: a theoretical perspective. - In: International Migration Review 44, 1: 1-38.

Donnan, H. (2001): Anthropology of borders. - In: SMELSER, N.J. \& P.B. BALTes (eds): International encyclopedia of the social \& behavioral sciences. - Amsterdam: Elsevier: 1290-1293.

Escobar, A. (2008): Territories of difference: place, movements, life, redes. - Durham, N.C.: Duke University Press.

GeIger, D. (ed.) (2008): Frontier encounters - indig- 
enous communities and settlers in Asia and Latin America. - Copenhagen: International Work Group for Indigenous Affairs.

Geiser, U., Müller-BöKer, U., Ramakumar, R., Shabaz, B., Steimann, B. \& S. Thieme (2011): Towards an analytical livelihoods perspective in critical development research. - In: HURNI, H. \& U. WIESMANN (eds): Research for sustainable development: foundations, experiences, and perspectives. $-=$ Perspectives of the Swiss National Centre of Competence in Research North-South, Vol. 6, Berne: 257-271.

Guarnizo, L.E. (2003): The economics of transnational living. - In: International Migrant Review 37, 3 : 666-699.

HARVEY, D. (1990): The condition of postmodernity: an enquiry into the origins of cultural change. - Oxford: Blackwell.

Kofman, E. (2007): The knowledge economy, gender and stratified migrations. - In: Studies in Social Justice 1, 2: 122-135.

Korf, B., Engeler, M. \& T. Hagmann (2010): The geography of warscape. - In: Third World Quarterly 31, 3:385-399.

Marston, S.A., Jones III, J.P. \& K. WoodWARd (2005): Human geography without scale. - In: Transactions of the Institute of British Geographers NS 30: 416-432.

Migdal, J. (2004): Mental maps and virtual checkpoints: struggles to construct and maintain state and social boundaries. - In: Migdal, J. (ed.): Boundaries and belonging: states and societies in the struggle to shape identities and local practices. - Cambridge: Cambridge University Press: 3-26.

Mitchell, T. (2009): How neoliberalism makes its world. - In: Mirowski, P. \& D. Plehwe (ed.): The road from Mont Pèlerin: the making of the neoliberal thought collective, Cambridge, MA: Harvard University Press: 386-416.

Muniesa, F., Millo, Y. \& M. Callon (2007): An introduction to market devices. - In: Muniesa, F., Millo, Y. $\&$ M. CALLon (eds): Market devices. - Oxford: Blackwell: $1-12$.

Poertner, E., Junginger, M. \& U. Müller-BöKer (2011): Migration in Far West Nepal. Intergenerational linkages between internal and international migration of rural-to-urban migrants. - In: Critical Asian Studies 43, 1:23-47.

ReID, R.J. (2011): Frontiers of violence in North-East Africa. - Oxford: Oxford University Press.

Robertson, R. (1995): Glocalization: time-space and homogeneity-heterogeneity. - In: FeATHERSTONE, M., LASH, S. \& R. ROBERTSON (eds): Global modernities. London: Sage: 25-44.

Schmidt-Kallert, E. (2009): A new paradigm of urban transition: tracing the livelihood strategies of multi-locational households. - In: Die Erde 140, 3: 319-336.

ScotT, J.C. (2009): The art of not being governed: an anarchist history of upland Southeast Asia. - New Haven, CT: Yale University Press.

Tejada Guerrero, G. \& J.-C. Bolay (2005): Enhancing development through knowledge circulation: a different view of the migration of highly skilled Mexicans. - = Global Migration Perspectives No. 51 .

ThIEME, S. (2008): Sustaining livelihoods in multi-local settings: possible theoretical linkages between transnational migration and livelihood studies. - In: Mobilities 3, 1: 51-71.

Thieme, S., Müller-Böker, U. \& N. Backhaus (2011): Women's livelihoods in a transnational social space: labour migration from Far West Nepal to Delhi, India. - In: RAJU, S. (ed.): Gendered geographies: space and place in South Asia. - New Delhi: Oxford University Press: 60-81.

United Nations Development Programme - UNDP (2009): Human development report 2009. Overcoming barriers: human mobility and development. - New York: United Nations Development Programme.

UNESCO (1998): World declaration on higher education for the twenty-first century: vision and action. - Adopted by the World Conference on Higher Education, October 5-9, Paris, http://www.unesco.org/education/educprog/wche/declaration_eng.htm 7.10.2011. WATTS, M. (2000): Struggles over geography: violence, freedom and development at the millennium. - = Hettner-Lectures 3, Heidelberg: Department of Geography, University of Heidelberg.

Wescot, C. \& J.M. Brinkerhoff (eds) (2006): Converting migration drains into gains: harnessing the resources of overseas professionals. - Manila: Asian Development Bank.

WiLliams, A.M. (2007): International labour migration and tacit knowledge transactions: a multi-level perspective. - In: Global Networks 7, 1: 29-50.

Zoomers, A., Rivera-Salgado, G., Asis, M.M.B., Piper, N., Raghuram, P., Awumbila, M., Manuh, T. \& J. SCHAPENDONK (2009): Migration in a globalizing world: knowledge, migration and development. - In: MoLeNAAR, H., Box, L. \& R. EngelHARD (eds): Knowledge on the move. Emerging agendas for development-oriented research. - Leiden: International Development Publications: 89-121.

\section{Summary: Worlds of difference, different worlds: geographies of globalization}

This article introduces current human geography research at the Department of Geography in Zurich around the notion of geographies of globalization. After mapping out a conceptual landscape of geographies of globalization as worlds of difference, three collaborative research areas are introduced which share a commitment to north-south-relations and a concern for processes of uneven development and fragmentation: «People: Migration», «State: Frontier» 
and «Economy: Geographies of marketization». The first studies the multi-local connections and social spaces of migrants, the second explores the intricate relationship between state, territory and the question of where «the state ends» and the third is concerned with the emergence of market orders and their uneven spatial and social expansion.

Keywords: globalization, flat ontology, migration, frontier, marketization

\section{Zusammenfassung: Welten der Unterschiede, unter- schiedliche Welten: Geographien der Globalisierung} In diesem Beitrag wird die humangeographische Forschung am Geographischen Institut der Universität Zürich unter dem programmatischen Label «geographies of globalization» vorgestellt. Nach einer Kartierung der konzeptionellen Landkarte von Geographien der Globalisierung als Welten der Differenz zeigen wir drei Forschungsgebiete auf, die das Interesse an den Nord-Süd-Beziehungen und an Prozessen ungleicher Entwicklung und Fragmentierung teilen: (1) «Menschen: Migration» behandelt die multi-lokalen Verbindungen und sozialen Räume von Migranten und Migrantinnen, (2) «Staat: Grenze» beschäftigt sich mit den verschlungenen Beziehungsgefügen zwischen Staat, Territorialität und der Frage wo «der Staat endet», und (3) «Wirtschaft: Geographien der Vermarktlichung» befasst sich mit der Emergenz von Marktordnungen und ihrer ungleichen räumlichen und sozialen Expansion.

Schlüsselwörter: Globalisierung, flache Ontologie, Migration, Grenze, Vermarktlichung

\section{Résumé: Mondes de différences, différents mondes: les géographies de la mondialisation}

Cette contribution présente la recherche en géographie humaine de l'Institut de Géographie de l'Université de Zurich à travers le concept des géographies de la mondialisation. Après avoir présenté une cartographie des géographies de la mondialisation, trois domaines de recherche focalisant sur les rapports Nord-Sud et les processus de développement inégal et de fragmentation sont exposés: (1) «Population: migration» traite des interconnexions multi-locales et des espaces sociaux des migrants; (2) «Etat: frontière» présente les relations sinueuses entre l'Etat, la territorialité et les limites extérieures de l'Etat; et (3) «Economie: les géographies de la marchandisation», centrée sur l'émergence de l'ordre des marchés et sur leur expansion spatiale et sociale inégale.

Mots-clés: mondialisation, ontologie plate, migration, frontière, marchandisation

Prof. Dr. Norman Backhaus, Prof. Dr. Christian Berndt, Prof. Dr. Benedikt Korf, Prof. Dr. Ulrike Müller-Böker, Department of Geography, University of Zurich, Winterthurerstrasse 190, CH-8057 Zurich, Switzerland.

e-mail:

norman.backhaus@geo.uzh.ch

christian.berndt@geo.uzh.ch

benedikt.korf@geo.uzh.ch

ulrike.mueller-boeker@geo.uzh.ch

\section{Manuskripteingang/received/manuscrit reçu le} 17.10.2011

Annahme zum Druck/accepted for publication/accepté pour publication: 27.4 .2012 